\title{
Agronomic responses of three potted Crysanthemum (Dendranthema grandiflora Tzvelev) varieties to inorganic and organic fertilizers
}

\author{
Rika Meilasari ${ }^{1}{ }^{*}$, Kurnia Yuniarto $^{2}$, Eka Mirnia ${ }^{1}$, Yuniarti $^{1}$, and Ratna Andam Dewi ${ }^{1}$ \\ ${ }^{1}$ Assessment Institute for Agricultural Technology of West Sumatra, Jalan Raya Padang Solok Km.40 \\ Sukarami, Kab. Solok. West Sumatera, Indonesia. \\ ${ }^{2}$ Indonesian Ornamental Crop Research Institute, Jl. Raya Pacet- Ciherang Cianjur West Java, \\ Indonesia
}

\begin{abstract}
Potted chrysanthemums as one of high-demand potted ornamental plants are mostly cultivated using inorganic fertilizers. The organic fertilizers use as an alternative and complementary to inorganic fertilizers on potted chrysanthemum cultivation needs to be studied further. This study aims to determine the response of inorganic and organic fertilizer to agronomic characters of three potted Chrysanthemum varieties. The research was carried out in West Sumatra AIAT's greenhouse from October to December 2020 using split-plot design with three replications. The main plots were fertilizer treatments (control, inorganic fertilizers, Bio-urine organic fertilizers) and sub-plots consisted of three potted chrysanthemum varieties (Armita, Avanthe, and Naura). Bio-urine organic fertilizers nutrient content $\mathrm{N}, \mathrm{P}$ and $\mathrm{K}$. The results showed that agronomic character of plant height, leaf length, leaf width, and the number of internodes resulted from type of fertilization treatments were significantly different. The highest plant height, leaf width, and number of internodes were significantly achieved in inorganic fertilizers then followed by Bio-urine organic fertilizers and control. The highest growth for the characters of plant height, stem diameter, leaf length, leaf width, petiole length, and flower diameter were attained from Avanthe. The interaction between fertilizers types and varieties was not significantly different in all observed characters.
\end{abstract}

\section{Introduction}

Chrysanthemum (Dendranthema grandiflora Tzvelev) is one of the ornamental plants of the Asteraceae family. This plant is one of the tops of cuts and potted flowers in world trade [1]. Zhang et al. stated that the demand for chrysanthemums is increasing worldwide for both cut flowers, garden plants, potted plants, and ground cover plants [2]. In Indonesia, chrysanthemums have also become one of the main ornamental plants in the floriculture business. The chrysanthemum industry is growing rapidly which is marked by an increase in

*Corresponding author: rimeisa@yahoo.com 
planting area, production, productivity, export value and the number of farmers who plants it [3]. Data from the Ministry of Agriculture in 2018 showed that the production of chrysanthemum cut flowers was ranked first in Indonesia with a total of 488,176,610 stalks. The production of chrysanthemum cut flowers was far above the production of other cut flowers where the production of rose cut flowers was 202,065,050 stalks, tuberose production $116,909,764$ stalks, orchid production 24,717,840 stalks, gerbera 26,680,911 stalks, anthurium production 5,390,911 stalks, carnation flowers 1,732,585 stalks and gladiolus $1,412,553$ stalks [4].

Chrysanthemum is an ornamental plant that blooms beautifully, so the beauty of its flowers is the main factor in the superiority of this plant [5]. The various types, shapes, and colors of chrysanthemums make these flowers very popular in the community [6]. The great demand for Chrysanthemum cut flowers by consumers is used for various purposes such as room decoration for various events and flower arrangements. Chrysanthemums are also cultivated as potted ornamental plants which have high demand in the market. This type of chrysanthemum is very suitable as indoor and outdoor decoration as well as for temporal garden decoration [7]. It is widely used to decorate hotel lobbies, offices, restaurants, and homes [8]. Various flower colors and shapes as well as affordable prices are considered by consumers to choose this plant as an ornamental plant for various decorative purposes.

Potted chrysanthemum production in Indonesia has been cultivated by both farmers and companies. Chrysanthemum plants are generally cultivated vegetatively through cuttings [9]. The success of chrysanthemum cultivation is influenced by various environmental factors, such us the availability of nutrients [10]. In potted chrysanthemum cultivation, farmers and entrepreneurs generally use liquid inorganic fertilizer given through the leaves as an additional source of nutrition for potted chrysanthemum plants. While the use of liquid organic fertilizer given through the leaves as an alternative source of chrysanthemum plant nutrients in pots has not been widely used. Liquid fertilizer is a relatively cheap fertilizer alternative because the raw materials can be derived from agricultural or livestock waste which is abundantly available and easily obtained [11]. The use of organic fertilizers derived from livestock waste can reduce farmer dependences on the use of chemical fertilizers [12].

Organic fertilizer derived from cow urine is one of the organic fertilizers that is widely used as an inorganic fertilizer's alternative in various plant cultivations. The analysis results of cow urine liquid fertilizer conducted by Pangaribuanet.al. showed a total $\mathrm{N}$ content of 6657.08 ppm, a P content of $12.21 \mathrm{ppm}$ and a K content of $2738.05 \mathrm{ppm}$ [13]. The main role of the $\mathrm{N}$ nutrient for plants is to increase plant growth, especially stems, branches and leaves. Furthermore, $\mathrm{N}$ plays an important role in the formation of forage leaves which are very useful in the process of photosynthesis, as stated by Lingga and Marsono, in Aisyah [14]. Mappanganro showed that the use of cow POC enhanced by fermented cow urine gave good results on the growth of strawberry plants [15]. The application of cow biourine on pakchoy plants had a significant effect on the addition of plant wet weight [16] and the use of $25 \%$ concentration of this biourine gave a similar result with inorganic fertilizers in cocoa nurseries [17]. Aisyah et al. also reported that the nutrients contained in cow urine had a positive effect on mustard plants (Brassica juncea L.), which was able to increase the plant's vegetative growth. Application of cow urine POC with a dose of $15 \%-45 \%$ increased the height of mustard plants by $2.7 \mathrm{~cm}$, and a dose of $45 \%$ cow urine has not shown maximum results so it is still possible to increase the dose [14].

Based on this, the cow urine POC can be applied as an alternative fertilizer in potted chrysanthemum cultivation. The use of cow urine POC as an alternative liquid inorganic fertilizer in potted chrysanthemum cultivation needs to be studied further. This study aims to determine the response of inorganic and organic fertilizer to agronomic characters of three potted Chrysanthemum varieties. 


\section{Methodology}

This research was conducted in the West Sumatra AIAT's green house with an altitude of $1,000 \mathrm{~m}$ above sea level from October to December 2020. The study was conducted using a split-plot design which was repeated 3 times. The first factor or main plot is the type of fertilizer used (P) with 3 levels: P1 = control, P2 = inorganic fertilizers (Gandasil D), P3 = Bio-urine organic fertilizers. The bio-urine used is derived from cow urine. The second factor or subplot was the potted chrysanthemum variety (V) with 3 levels, namely V1 = Armita Agrihorti, V2 = Avanthe Agrihorti and V3 = Naura Agrihorti.

The chrysanthemum seeds used were rooted cuttings, planted in plastic pots with a diameter of $17 \mathrm{~cm}$. A mixture of soil + compost + husk charcoal with a ratio of 2:1:1 was used as the planting medium. In each pot were planted 5 chrysanthemum cuttings. Day length was given up to 18 days after planting (DAP). At 8 DAP, apical buds were pinched or removed to trigger the growth of lateral branches. Watering was done 2-3 times a week by looking at the condition of the growing media. Prevention of plant pests and diseases was done by spraying fungicides and insecticides once a week. Treatment of inorganic and organic fertilizers was carried out 2 times a week starting at 14 DAP. The dose of inorganic fertilizer used is 2 grams per liter of water, and the dose of liquid organic fertilizer bio-urine used was $100 \mathrm{ml}$ per liter of water. Fertilization was applied by spraying on the leaves and plants.

Observations were made when the plants had flowered. Observation parameters included plant height, stem diameter, leaf length, leaf width, number of internodes, number of branches, number of flowers, petiole length, and flower diameter. The obtained data were analyzed using analysis of variance. If there was a significant difference between the treatments, further tests were carried out using Duncan's Multiple Distance Test with a level of $5 \%$.

\section{Results and discussion}

The analysis of variance result showed that there were significant differences in several agronomic characters of potted chrysanthemums to various types of fertilizers (P), and varieties $(\mathrm{V})$, but there was no significant difference in the interaction of fertilizer types and varieties. The results of the analysis of variance of potted chrysanthemum's agronomic character's response to fertilizer treatment, varieties, and their interactions are presented in Table 1 .

Table 1. The results of analysis of variance of potted chrysanthemum's agronomic characters response to fertilizer, varieties, and their interactions

\begin{tabular}{|l|c|c|c|}
\hline \multirow{2}{*}{\multicolumn{1}{c|}{ Parameter }} & \multicolumn{3}{c|}{ Treatment } \\
\cline { 2 - 4 } & Fertilizer (P) & Variety (V) & Interaction P x V \\
\hline Plant height & $* *$ & $*$ & $\mathrm{~ns}$ \\
\hline Stem diameter & $\mathrm{ns}$ & $*$ & $\mathrm{~ns}$ \\
\hline Leaf length & $* *$ & $*$ & $\mathrm{~ns}$ \\
\hline leaf width & $* *$ & $\mathrm{~ns}$ & $\mathrm{~ns}$ \\
\hline Number of internodes & $* *$ & $*$ & $\mathrm{~ns}$ \\
\hline Number of branches & $\mathrm{ns}$ & $\mathrm{ns}$ & $\mathrm{ns}$ \\
\hline Number of flowers & $\mathrm{ns}$ & $*$ & $\mathrm{~ns}$ \\
\hline Petiole length & $\mathrm{ns}$ & $*$ & $\mathrm{~ns}$ \\
\hline Flower diameter & $\mathrm{ns}$ & & \\
\hline
\end{tabular}

$* *=$ highly significantly different $(\mathrm{P}<0,01) ; *=$ significantly difference $(\mathrm{P}<0,05) ;$ ns $=$ not-significantly difference $(\mathrm{P}>0,05)$. 


\subsection{Agronomic characters response of potted chrysanthemum to fertilizer}

The significant differences of agronomic characters of potted chrysanthemum's plant height, leaf length, leaf width, and the number of internodes between types of fertilization treatment are shown in table 2 .

Table 2. Agronomic characters response of potted chrysanthemum to fertilizer

\begin{tabular}{|c|c|c|c|c|}
\hline $\begin{array}{c}\text { Fertilizer } \\
\text { Treatment }\end{array}$ & Plant height & Leaf length & Leaf width & $\begin{array}{c}\text { Number of } \\
\text { internodes }\end{array}$ \\
\hline P1 & $16.68 \mathrm{~b}$ & $4.980 \mathrm{a}$ & $2.261 \mathrm{~b}$ & $12.61 \mathrm{~b} \mathrm{ab}$ \\
\hline P2 & $19.48 \mathrm{a}$ & $3.859 \mathrm{~b}$ & $2.931 \mathrm{a}$ & $13.54 \mathrm{a}$ \\
\hline P3 & $19.28 \mathrm{~b}$ & $3.757 \mathrm{~b}$ & $2.233 \mathrm{~b}$ & $11.50 \mathrm{~b}$ \\
\hline
\end{tabular}

Numbers followed by the same letter in the same column show not significantly different according to Duncan's Multiple Distance Test at 5\% level.P1 = control, P2 = inorganic fertilizers, P3 = Bio-urine organic fertilizers

The use of inorganic fertilizers gave the best response for plant height, leaf width, and the number of internodes characters, while for the character of leaf length, the use of inorganic and organic fertilizers was not significantly different. Gandasil D inorganic fertilizer contains macronutrients $\mathrm{N}, \mathrm{P}$, and $\mathrm{K}$ and micronutrients $\mathrm{Mg}, \mathrm{Mn}, \mathrm{B}, \mathrm{Cu}, \mathrm{Co}, \mathrm{Zn}$, as well as vitamins aneurine, lactoflavin, and nicotinic acid amide. The liquid organic fertilizer Bio-urine has a high $\mathrm{N}$ content but has fewer micro-nutrients. Allegedly this affects the growth of potted chrysanthemum plants so its response was lower than inorganic fertilizers. Hadi showed that the application of Bio Sugih liquid supplementary fertilizer on polyploidy chrysanthemum genotypes showed an insignificant effect on plant height compared to controls [18]. Nugroho et al. also stated that there was no significant difference between the treatment of bio-urine concentrations of 0-, 250-, 500-, and 750-ml L-1 of water for the character of plant height, number of leaves, leaf length, and leaf width on chrysanthemum growth [10]. Urine from livestock is very easy to evaporate and lose, so the availability of nutrients is low, as stated by Lingga and Marsono, in Nugroho [10]. This is considered as one of the factors causing the growth of potted chrysanthemums treated with bio-urine liquid organic fertilizer had a lower agronomic response compared to inorganic fertilizers.

\subsection{Agronomic characters response of three potted chrysanthemum varieties}

Tabel 3. Agronomic characters response of three potted chrysanthemum varieties

\begin{tabular}{|c|c|c|c|c|c|c|c|}
\hline Variety & $\begin{array}{c}\text { Plant } \\
\text { height }\end{array}$ & $\begin{array}{c}\text { Stem } \\
\text { diameter }\end{array}$ & $\begin{array}{c}\text { Leaf } \\
\text { length }\end{array}$ & $\begin{array}{c}\text { leaf } \\
\text { width }\end{array}$ & $\begin{array}{c}\text { number } \\
\text { of } \\
\text { branches }\end{array}$ & $\begin{array}{c}\text { Petiole } \\
\text { length }\end{array}$ & $\begin{array}{c}\text { Flower } \\
\text { diameter }\end{array}$ \\
\hline V1 & $16.53 \mathrm{~b}$ & $0.243 \mathrm{c}$ & $4.700 \mathrm{a}$ & $2.609 \mathrm{a}$ & $3.803 \mathrm{a}$ & $2.726 \mathrm{~b}$ & $3.689 \mathrm{~b}$ \\
\hline $\mathrm{V} 2$ & $19.71 \mathrm{a}$ & $0.298 \mathrm{a}$ & $4.518 \mathrm{a}$ & $2.660 \mathrm{a}$ & $2.370 \mathrm{~b}$ & $3.799 \mathrm{a}$ & $4.590 \mathrm{a}$ \\
\hline $\mathrm{V} 3$ & $15.21 \mathrm{~b}$ & $0.249 \mathrm{~b}$ & $3.378 \mathrm{~b}$ & $2.157 \mathrm{~b}$ & $3.532 \mathrm{a}$ & $3.464 \mathrm{a}$ & $3.800 \mathrm{~b}$ \\
\hline
\end{tabular}

Numbers followed by the same letter in the same column show not significantly different according to Duncan's Multiple Distance Test at 5\% level. V1 = Arminta Agrihorti, V2 = Avanthe Agrihorti, P3 = Naura Agrihorti

The highest growth response for the characters of plant height, stem diameter, leaf length, leaf width, petiole length, and flower diameter of three potted chrysanthemum varieties tested was obtained in the Avanthe Agrihorti variety. While, the highest number of branches was produced by the varieties of Armita Agrihorti and Naura Agrihorti. The average plant height of the Avanthe Agrihorti variety was $19.71 \mathrm{~cm}$. In general, the appearance of potted 
ornamental plants that are in public demand has the character of plant heights ranging from 25-35 cm, having lush leaves, and uniform and compact flowers [19]. According to Cahyono, good quality potted chrysanthemums have a plant height of about $20-25 \mathrm{~cm}$. Based on this, the height of potted chrysanthemum plants as a result of this treatment is still below the ideal criteria for potted chrysanthemum plants [20]. Furthermore, the plant height, a large and sturdy stem diameter are also needed to support a good plant appearance. The Avanthe Agrihorti variety showed the largest average diameter value than other varieties and visually showed the sturdy performance.

The highest leaf length and leaf width parameters were also obtained in the Avanthe Agrihorti variety. This was consistent with plant height, in which the Avanthe Agrihorti variety has the tallest plant height among other varieties. Plant height and number of leaves are usually followed by an increase in leaf length and width [10].

On the number of branches character, the Naura Agrihorti variety showed the highest response but statistically, it was not significantly different from the Armita Agrihorti variety. In potted chrysanthemums, by pinching the apical buds, 3-4 lateral shoots are expected to grow from one pot of chrysanthemum plants [20]. The biggest number of branches in potted chrysanthemum will give a better plant performance and lush appearance.

The average response of the longest petiole length was found in the Avanthe variety but not significantly different from the Naura Agrihorti variety. In potted chrysanthemums, there is no limit on the ideal petiole length, but in general, the consumer's preference is a short petiole length. Furthermore, for the flower diameter character, the Avanthe Agrihorti variety showed the largest flower diameter of $4,590 \mathrm{~cm}$. Nurmalinda and Hayati stated that potted chrysanthemums with a flower diameter of $4 \mathrm{~cm}$ belong to the criteria for medium flower size [6].

\section{Conclusion}

The use of inorganic fertilizers in potted chrysanthemum cultivation gave significantly different agronomic characters responses for the characters of plant height, leaf length, leaf width and number of internodes. The agronomic responses of three potted chrysanthemum varieties showed that the Avanthe Agrihorti variety had the highest plant height, stem diameter, leaf length, leaf width, number of internodes, petiole length, and flower diameter among the three varieties tested. There was no significant interaction between the type of fertilizer treatment and potted chrysanthemum varieties. 


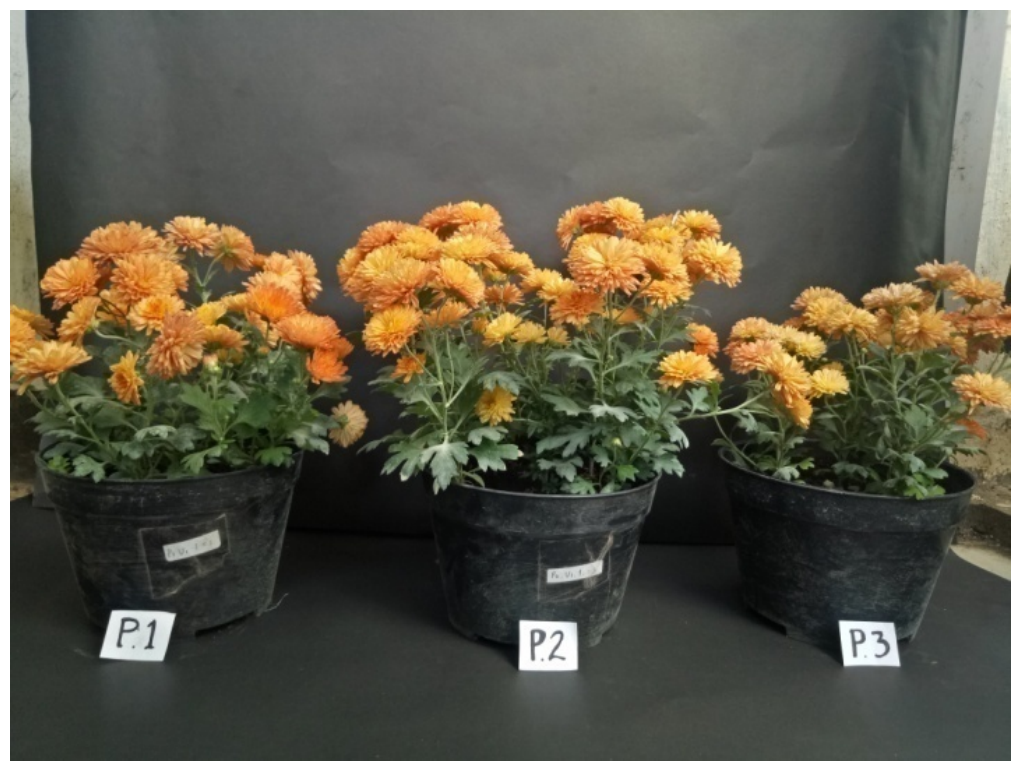

Fig 1. V1 = Armita Agrihorti Variety; P1 = control, P2 = inorganic fertilizer, P3 = bio-urine liquid organic fertilizer

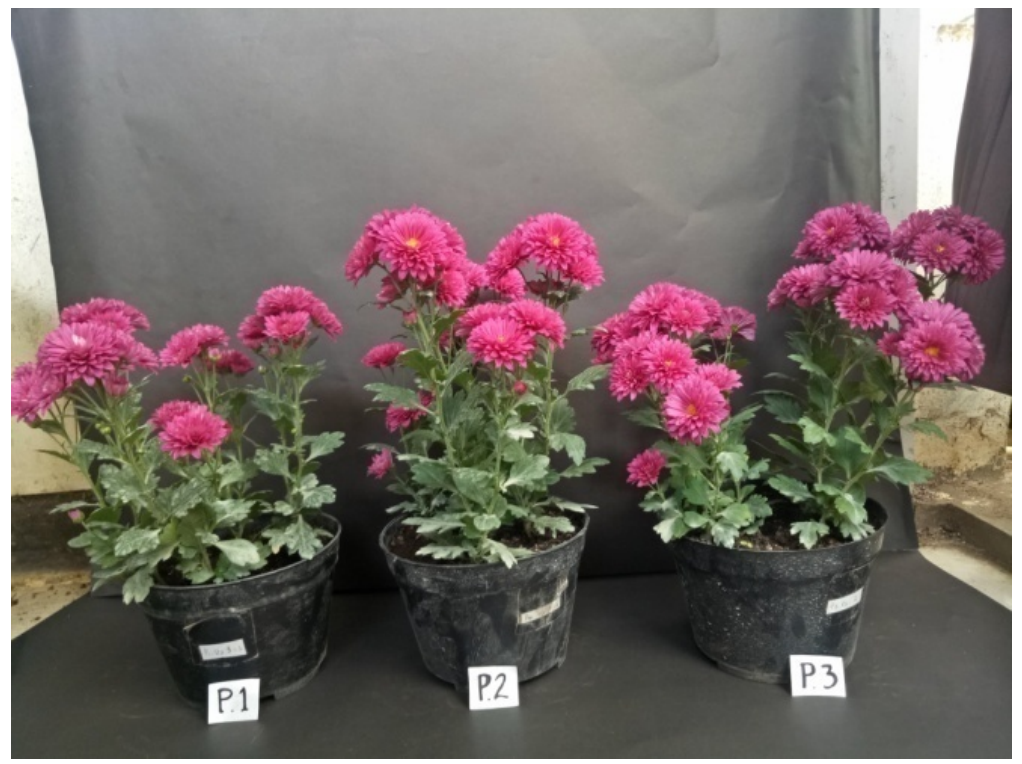

Fig 2. V2 = Avanthe Agrihorti Variety; $\mathrm{P} 1=$ control, $\mathrm{P} 2=$ inorganic fertilizer, $\mathrm{P} 3=$ bio-urine liquid organic fertilizer 


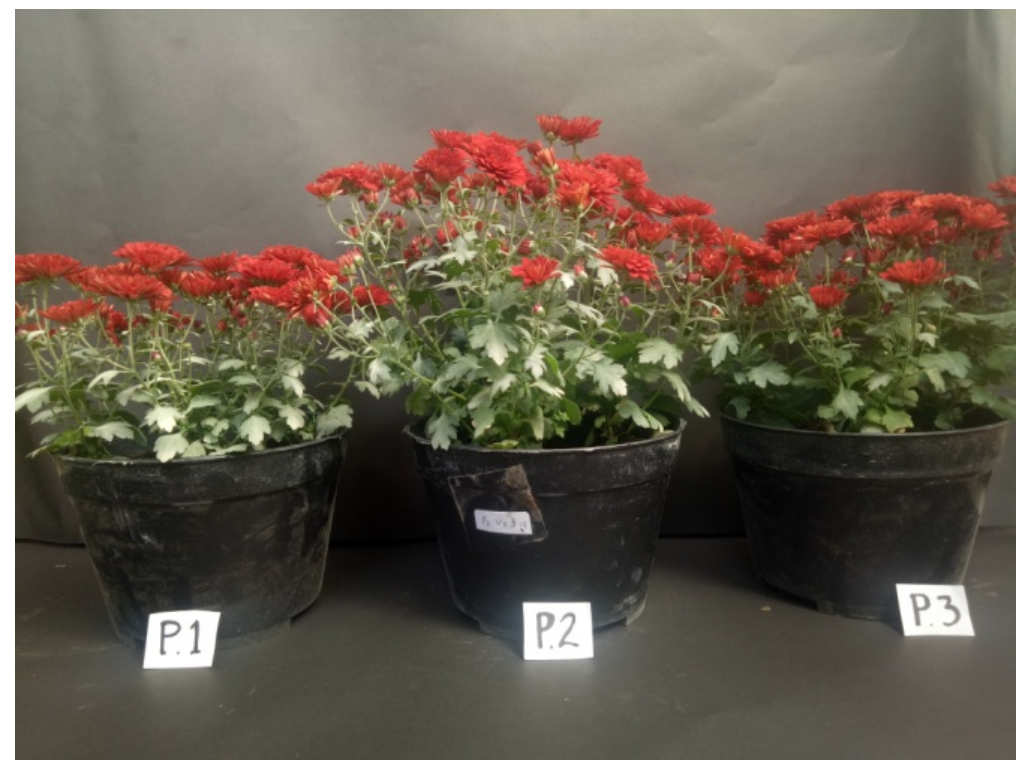

Fig 3. V3 = Naura Agrihorti Variety; $\mathrm{P} 1=$ control, $\mathrm{P} 2=$ inorganic fertilizer, $\mathrm{P} 3=$ bio-urine liquid organic fertilizer

\section{References}

1. A. Abrol, S. Dhiman, P. Sharma, M. Sharma, Journal of Hill Agriculture. 9, 2 (2018)

2. F. Zhang, S. Chen, F. Chen, W. Fang, Y. Deng, Q. Chang, P. Liu, J. Euphytica 177 (2010)

3. L. Sanjaya, B. Marwoto, R. Soehendi, The Development of Agricultural Innovation (Pengembangan Inovasi Pertanian) 8, 1 (2015)

4. Laporan Kinerja Direktorat Jenderal Hortikultura Tahun Anggaran 2020, (Kementerian Pertanian, Direktorat Jenderal Hortikultura, 2020)

5. R. Meilasari, W. A. Qosim, Murdaningsih, K. Yuniarto, J. Hort. 25, 2 (2015)

6. Nurmalinda, N. Q. Hayati, J. Hort. 24, 4 (2014)

7. Suryawati, R. Meilasari, K. Yuniarto. Performance of a cross of potted chrysanthemum (Dendranthema grandiflora Tzvelev) Asley x Bonny variety, in Proceedings of the 2016 National Seminar and Congress of the Indonesian Agronomy Association (Peragi): Seed Self-Reliance to Build Food and Industry Sovereignty. 27 April 2016, Bogor, Indonesia, (2016)

8. D. Setiadi, Noertjahyani, Suparman, Journal Kultivasi 17, 1 (2018)

9. J.A.T. da Silva. Plant Cell Tissue and Organ Culture 79 (2004)

10. E. D. S. Nugroho, D. Histifarina, A. Elonard, Jour. Agroekotek 11, 1 (2019)

11. K. A Wijaya, Journal Agritrop. 11, 1 (2013)

12. S. Rohani, S.N. Sirajuddin, M. I. Said, M. Z. Mide, Nurhapsa, Journal Panrita Abdi 1, 1 (2016)

13. D.H. Pangaribuan, Sarno, M.C. Kurniawan, Journal Metamorfosa. IV, 2 (2017)

14. S. Aisyah, N. Sunarlim, B. Solfan, J. Agrotechnologi. 2, 1 (2011)

15. N. Mappanganro, J. Biogenesis. 1, 2 (2013)

16. Y. Nuraini, R. E. Asgianingrum, J. Hort. Indonesia 8, 3 (2017)

17. S. Rosniawaty, R. Sudirja, H. Afrianto, Journal Kultivasi 14, 1 (2015)

18. R. A. Hadi. J.Agrowiralodra. 2, 2 (2019) 
19. D. A. Kusumawardani, D. Hariyono, Journal of Plant Production. 8, 3 (2020)

20. F. B. Cahyono. Potted Chrysanthemum. Guidance on Building Agribusiness.First Edition (PT. Elex Media Komputindo, Gramedia Group Jakarta, 1999) 